University of New Hampshire

University of New Hampshire Scholars' Repository

$12-1996$

\title{
Climate and nitrogen controls on the geography and timescales of terrestrial biogeochemical cycling
}

\author{
David S. Schimel \\ NCAR \\ Rob Braswell \\ University of New Hampshire - Main Campus, rob.braswell@unh.edu \\ R McKeown \\ NCAR
}

Dennis S. Ojima

The H. John Heinz III Center for Science, Economics, and the Environment, Washington, DC

W J. Parton

Colorado State University - Fort Collins

See next page for additional authors

Follow this and additional works at: https://scholars.unh.edu/earthsci_facpub

\section{Recommended Citation}

Schimel, D. S., B. H. Braswell, R. McKeown, D. S. Ojima, W. J. Parton, and W. Pulliam (1996), Climate and nitrogen controls on the geography and timescales of terrestrial biogeochemical cycling, Global Biogeochem. Cycles, 10(4), 677-692, doi:10.1029/96GB01524.

This Article is brought to you for free and open access by the Earth Sciences at University of New Hampshire Scholars' Repository. It has been accepted for inclusion in Earth Sciences Scholarship by an authorized administrator of University of New Hampshire Scholars' Repository. For more information, please contact Scholarly.Communication@unh.edu. 


\section{Authors}

David S. Schimel, Rob Braswell, R McKeown, Dennis S. Ojima, W J. Parton, and W Pulliam 


\title{
Climate and nitrogen controls on the geography and timescales of terrestrial biogeochemical cycling
}

\author{
D. S. Schimel, B. H. Braswell' ${ }^{1}$, and R. McKeown \\ National Center for Atmospheric Research, Boulder, Colorado \\ D. S. Ojima, W. J. Parton, and W. Pulliam \\ Natural Resources Ecology Laboratory, Colorado State University, Fort Collins
}

\begin{abstract}
We used the terrestrial ecosystem model "Century" to evaluate the relative roles of water and nitrogen limitation of net primary productivity, spatially and in response to climate variability. Within ecology, there has been considerable confusion and controversy over the largescale significance of limitation of net primary production (NPP) by nutrients versus biophysical quantities (e.g., heat, water, and sunlight) with considerable evidence supporting both views. The Century model, run to a quasi-steady state condition, predicts "equilibration" of water with nutrient limitation, because carbon fixation and nitrogen fluxes (inputs and losses) are controlled by water fluxes, and the capture of nitrogen into organic matter is governed by carbon fixation. Patterns in the coupled water, nitrogen, and carbon cycles are modified substantially by ecosystem type or species-specific controls over resource use efficiency (water and nitrogen used per unit NPP), detrital chemistry, and soil water holding capacity. We also examined the coupling between water and nutrients during several temperature perturbation experiments. Model experiments forced by satellite-observed temperatures suggest that climate anomalies can result in significant changes to terrestrial carbon dynamics. The cooling associated with the Mount Pinatubo eruption aerosol injection may have transiently increased terrestrial carbon storage. However, because processes in the water, carbon, and nitrogen cycles have different response times, model behavior during the return to steady state following perturbation was complex and extended for decades after 1- to 5year perturbations. Thus consequences of climate anomalies are influenced by the climatic conditions of the preceding years, and climate-carbon correlations may not be simple to interpret.
\end{abstract}

\section{Introduction}

Terrestrial ecosystem models have progressed from early, highly aggregated models to include mechanistic or parametric representations of the ecological, hydrological, and biogeochemical processes that dynamically control carbon storage and net primary productivity (NPP) [Melillo et al., 1993; Potter et al., 1993; Schimel et al., 1994]. Process-based models for terrestrial biogeochemistry are important for furthering ecosystem science because they allow the extrapolation of fluxes to large spatial scales, as well as the comparison of model predictions to the growing body of global observations. Whereas most extant ecological data are site- or systemspecific (in contrast to the standardized sectional or global sampling widely used in meteorology and oceanography for seawater $\mathrm{PCO}_{2}$, atmospheric $\mathrm{CO}_{2},{ }^{13} \mathrm{CO}_{2}$, and physical variables), collaborative activities such as the International Geosphere-Biosphere Programme (IGBP) and new satellite

\footnotetext{
${ }^{1}$ Also at Institute for Earth, Oceans and Space, University of New Hampshire, Durham
}

Copyright 1996 by the American Geophysical Union.

Paper number 96GB01524

0886-6236/96/96GB-01524\$12.00 techniques are resulting in improved global ecosystem data. Spatially resolved process models both provide insights into large-scale controls and provide a consistent framework for comparisons with existing observations.

Spatial ecosystem models are derived from theory linking climate, soil properties, and species- or growth form-specific traits to biogeochemical responses of plants and microorganisms [Farqhuar et al., 1980; Melillo et al., 1984; Bloom et al., 1985; Chapin et al., 1987; Nobel, 1991; Running and Nemani, 1991]. Many studies have demonstrated nutrient limitation of terrestrial primary productivity (i.e., added nutrients lead to additional plant growth and carbon storage) [Vitousek and Howarth, 1991; Schimel, 1995]; however, large-scale patterns in terrestrial primary productivity, soil carbon, and soil metabolism can often be explained from simple equations using climate parameters (precipitation, actual evapotranspiration, and solar radiation) [Lieth, 1975; Post et al., 1985; Uchijima and Seino, 1985; Sala et al., 1988; Potter et al., 1993; Gifford, 1994; Zak et al., 1994]. Within grasslands, empirical climate or soil-based models and process-based models have similar predictive power (Sala et al. [1988] or Burke et al. [1991] vs. Parton et al. [1987, 1994]). Intercepted solar radiation has also been suggested as a major control over NPP, although Field [1991] pointed out the circularity inherent in observed correlations between intercepted radiation and plant growth. 
The climatic versus nutrient limitation views inherent in modern ecology (discussed by Schulze et al. [1989] and Schimel et al. [1991]) have important implications for predictions of future environmental changes and for the application of models in land management. Keeling et al. [1995] argued that on the decadal timescale, the observational record suggests that warming causes increased $\mathrm{CO}_{2}$ uptake by the biosphere but with a 2-year lag. This phenomenon, if true, is inconsistent with direct biophysical effects, which are nearly instantaneous, but is consistent with responses to a warminginduced release of nutrients and subsequent increases in NPP, as is suggested by models of long-term effects [VEMAP Members, 1995]. In a recent study, response of modeled carbon storage to increasing $\mathrm{CO}_{2}$ was reduced by increasing nutrient limitation [VEMAP Members, 1995]. Other work suggests temperature responses will decrease as well [Schimel et al., 1994]. The temperature response occurs because warming increases microbial respiration thereby causing reductions in soil carbon; but warming releases nutrients, which, in forests, can lead to increases in carbon storage in wood that are larger than the carbon losses from soils [VEMAP Members, 1995]. Because of this, the short-term effect of warming (carbon losses from soils) may be opposite in sign to the long-term effect (carbon gains in wood). However, if nutrient cycling equilibrates rapidly with climate and $\mathrm{CO}_{2}$ determinants of carbon storage (on annual to decadal timescales, for example, through nitrogen fixation [Gifford, 1994; Schimel, 1995; Schimel et al., 1995]), then nutrient feedbacks may be neglected in the big picture and attention focused on $\mathrm{CO}_{2}$ and biophysical constraints. If nutrient cycling is uncoupled from climate and $\mathrm{CO}_{2}$ changes (e.g., controlled more by long-term pedogenic and geomorphic processes [Cole and Heil, 1981; Schimel et al., 1985]), then modeling nutrient cycles is essential to simulating future changes to ecosystems.

\section{Model Description and Methods}

Over the past decade, W.J. Parton and colleagues have developed the Century terrestrial ecosystem model, which now includes parameterization of the major pathways for carbon and nitrogen exchange, including atmospheric and biological $\mathrm{N}$ inputs and gaseous, biomass combustion-related and hydrological N losses [Parton et al., 1987, 1988, 1994; Schimel et al., 1990, 1991, 1994; Ojima et al., 1994]. Examination of the controls over carbon and nitrogen dynamics in the Century ecosystem model suggests a mechanism through which biophysical (water and temperature) and biogeochemical controls may become correlated. The distinguishing features of Century are first, the explicit partitioning of living biomass and dead organic matter into compartments defined by differing turnover times and second, the high degree of integration between biophysical and biogeochemical processes. For the living components, the model explicitly considers leaves, fine roots, coarse roots, branches, and stems, and for dead organic matter, the model is based on isotopic and other evidence for multiple turnover times in detritus and soil organic matter [Trumbore, 1993; Parton et al., 1994, 1995]. The structure of the carbon and nitrogen submodels are shown in Figures $1 \mathrm{a}$ and $1 \mathrm{~b}$. Full descriptions of the model are found in Parton et al. [1987, 1995]: below we describe features of the model and its global implementation that are new and/or impact the results described in this paper.

The gridded version of the model requires three types of information including inputs that are grid cell-specific and time varying (largely those related to the atmosphere), inputs that are grid cell-specific and fixed (mostly soil properties), and variables that describe physiological attributes of vegetation types that apply to all grid cells within a vegetation type. The model is integrated using monthly maximum and minimum temperatures and precipitation. Climate data used in this study are as described by Cramer et al. [1995] and derived from May et al. [1992].

The algorithm for NPP in Century is key to understanding the results presented in this paper. In Century, a "potential NPP" (NPP $)$ is computed using the following equation:

$$
N P P_{\mathrm{p}}=N P P_{\max } \cdot T \cdot M \cdot S,
$$

where $N P_{\max }$ is a biophysically defined maximum NPP, $T$ is the effect of temperature on NPP, M is the effect of soil water, and $S$ is the effect of self shading. The functional forms for $T$, M, and S are given by Parton et al. [1993]. This climatically limited NPP is then constrained by nutrient availability. The nutrient-limited NPP equation estimates the portion of NPP that can be achieved while maintaining appropriate tissue $C: N$ stoichiometry:

$$
N P P_{\mathrm{u}}=\Sigma_{1}\left(N_{\text {avoli }} \cdot w_{\text {root }}+N_{\text {tri }}\right) \cdot F_{1} \cdot C: N_{\mathrm{i}} \quad \mathrm{i}=1 \text {, nparts, }
$$

where NPP is the nutrient-limited NPP, $N_{\text {avail }}$ is the available mineral $N$ in soil solution $\left(\mathrm{N}_{\text {inorg }}\right.$ ) plus $\mathrm{N}$ in plant storage pools (plant storage results from $N$ that is resorbed from senescent foliage and is available for new growth in the spring or following drought in perennial vegetation), and $N_{\text {fux }}$ is plant $N$ fixation. In turn, $\mathbf{N}_{\text {inorg }}$ is the sum of net mineralization plus microbial fixation plus atmospheric deposition. The factor " $w_{\text {rood }}$ " weights plant nutrient uptake based on root biomass (if root biomass is zero, $w_{\text {roox }}$ is zero; at an upper threshold of root biomass, $w_{\text {root }}$ is one). $F_{j}$ and $C: N_{i}$ are the fraction of total potential plant $N$ uptake $\left(N_{\text {aval }} \cdot w_{\text {roo }}+N_{t i x}\right)$ allocated to plant part $i$ and the C:N ratio of plant part $i$, respectively. These are indexed over plant parts (nparts: roots, leaves, and fine and coarse wood). The C:N ratios of plant parts float between tissue type-specific upper and lower critical levels (C: $N_{L \text { min }}$ and $\left.\mathrm{C}: \mathrm{N}_{\mathrm{h}, \max }\right)$ and are scaled by:

$$
C: N_{\mathrm{i}}=f\left(\left[N_{\text {wail }} \cdot w_{\text {root }}+N_{\text {fix }}\right] / \text { demand }\right) \text {, }
$$

where demand is computed from $\Sigma_{i}\left(F_{i} \cdot N P P / C: N_{i, \min }\right)$. The scalar function $f$ is defined such that $C: N_{i}$ equals $C: N_{i, \max }$ when supply equals demand, and approaches $C: N_{i, \text { min }}$ when supply is limiting. That is, $\mathrm{C}: \mathrm{N}$ ratios are scaled by the ratio of $\mathrm{N}$ available for plant uptake divided by the amount of $\mathrm{N}$ that a plant would use if it could get all the nitrogen needed to grow at the climate-limited rate. Thus the higher $\mathrm{NPP}_{p}$ is relative to $\mathrm{NPP}_{\mathrm{n}}$, the wider the plant $\mathrm{C}: \mathrm{N}$ ratios. Then, in effect, actual NPP is defined by:

$$
N P P=\min \left(N P P_{\mathrm{n}}, N P P_{\mathrm{p}}\right) .
$$

Although NPP, is nearly always less than $\mathrm{NPP}_{\mathrm{p}}$, if $\mathrm{NPP}_{\mathrm{p}}$ goes up, NPP will generally follow, because of (3), which allows $C: N$ ratios to float based on the $N$ supply/demand equation (unless the lower critical $C: N$ ratio threshold is reached). Experimental evidence supports floating $\mathrm{C}: \mathrm{N}$ ratios between years [Schimel et al., 1991]. If $\mathrm{N}$ availability goes up 


\section{SURFACE LITTER}

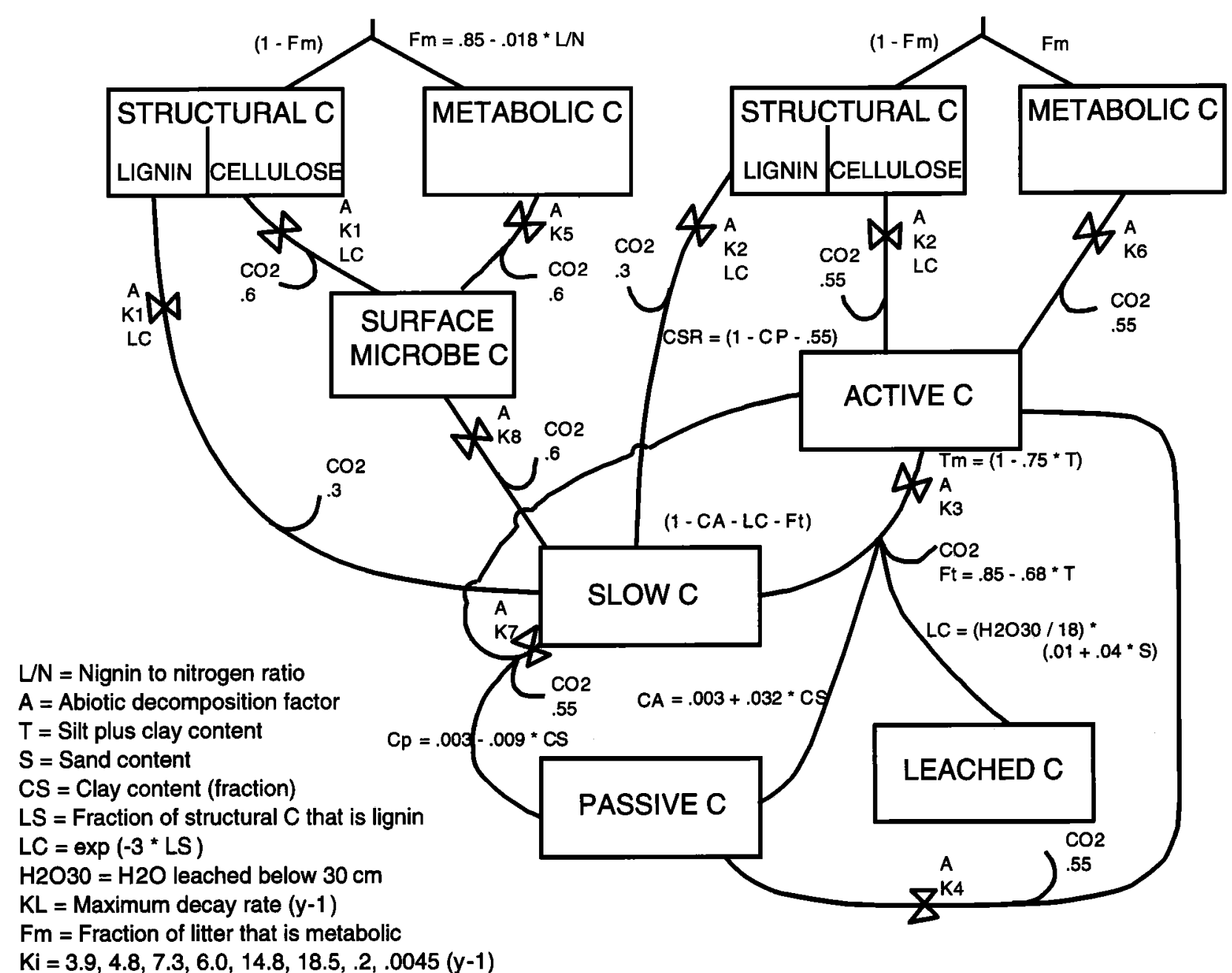

Figure 1a. Structure and main parameters of the carbon flow submodel of the Century model. The locus of controls are indicated in Figure $1 \mathrm{a}$ and the controlling parameters are indicated adjacent to Figure $1 \mathrm{a}$.

(e.g., if $\mathrm{N}$ mineralization increases because of warmer or wetter soils [Schimel et al., 1994]), NPP will increase as NPP more nearly approaches $\mathrm{NPP}_{\mathrm{p}^{*}}$. Conditions that modify $\mathrm{NPP}_{\mathrm{p}}$ (changes to temperature or precipitation) will also affect soil processes (and hence $\mathrm{N}_{\text {svai }}$ ) that are also influenced by $\mathrm{T}$ and $\mathrm{M}$ [see Schimel et al., 1994; Parton et al., 1995].

The model requires estimates of nitrogen fluxes into the system. As discussed below, budgetary nitrogen fluxes are critical to the model. Nitrogen enters ecosystems via several mechanisms including wet and dry deposition. We assume, based on extensive data analysis, that deposition is correlated with precipitation and thus use this correlation to produce a general field of $\mathbf{N}$ deposition mimicking observations [Parton et al., 1987; Schimel et al., 1990]. This relationship does not supply sufficient nitrogen in tropical regions to support observed NPP. A second equation relates $\mathrm{N}$ inputs to actual evapotranspiration (ET) (as modeled in Century):

$$
N_{\text {fix }}=0.008 *(E T-40) \text {. }
$$

If $\mathrm{N}_{\mathrm{ax}}$ is less than zero (ET less than $40 \mathrm{~cm} \mathrm{yr}^{-1}$ ), it is set to zero. This parameterization has no mechanistic basis but captures phenomenologically the fact that most observations of high rates of biological nitrogen fixation are from humid settings with high evapotranspiration and that these systems (tropical and temperate rainforests) have large $\mathrm{N}$ stocks and high losses (requiring high inputs) of $\mathrm{N}$ [e.g., Matson and Vitousek, 1987]. In Century, this provides a constant flux tuned to provide sufficient $\mathrm{N}$ to sustain observed NPP. In reality, biological nitrogen fluxes may occur at certain successional or climatic stages, rather than as a constant background process. The requirement to use this empirical and tuned parameterization reflects our ignorance of the biogeography and biogeochemistry of nitrogen fixation in natural ecosystems over long timescales [Eisele et al., 1989; Vitousek and Howarth, 1991; Schimel, 1995].

Soil properties required by Century include soil texture and depth. Texture is defined by the continuous distribution of soil in terms of size classes (percent sand, percent silt, and percent clay). These may be derived via a look-up table from maps in 


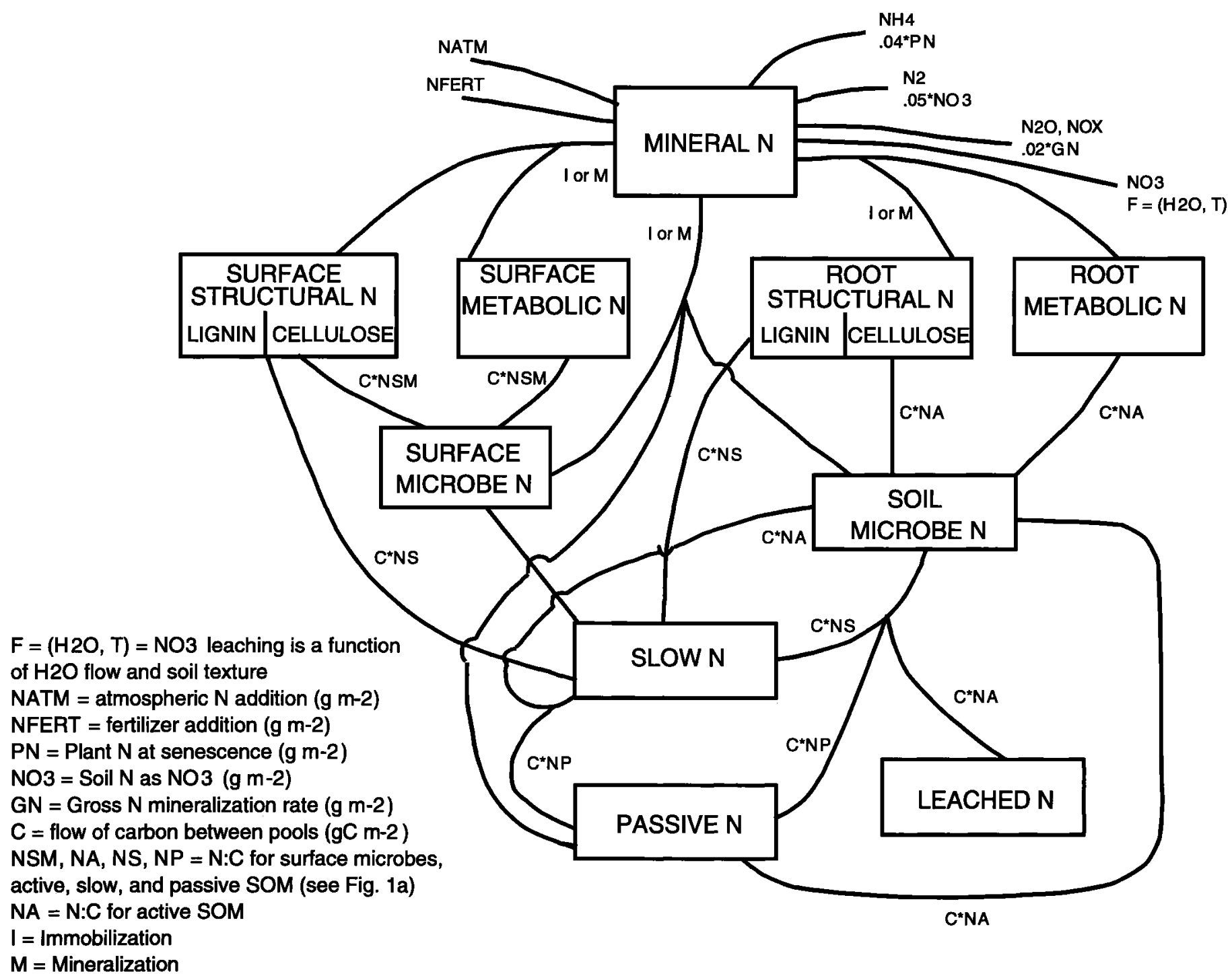

Figure 1b. As in Figure 1a, but showing the nitrogen fluxes and controls within Century.

which texture is defined categorically; in this case, the midpoint percentages of size classes are used for each category. For the simulations presented in this paper, soil. textures were prescribed according to Zobler's [1986] analysis of the Food and Agriculture Organization Soil Map of the World (see also Schimel et al. [1994]).

Century also requires some vegetation type-specific parameterizations [VEMAP Members, 1995; Schimel et al., 1996]. These include carbon-to-nutrient ratios by tissue type and nitrogen allocation between tissue types for each ecosystem type. Lacking a comprehensive theory of allocation, fundamental allocation relationships (percent of NPP allocated to wood vs. foliage vs. roots) are defined as a function of ecosystem type and as a function of plant size via allometric equations, designed to reproduce observations at calibration sites. This approach is based on a large database, reproduces observed allocation patterns at calibration and validation sites, and allows some changes in allocation proportions as trees or large shrubs become larger. It does not reproduce changes in allocation resulting from changes in resource availability, which have been observed and which may be significant [Ingestadt and Lund, 1986; Running and Hunt, 1993]. We adopted the more conservative approach of using parametric allocation equations because of the lack of general and proven theory for a resource-based approach [Running and Hunt, 1993] and the lack of parameters for a resource-based approach for many biomes.

Three model experiments are reported in this paper. First, we carried out a global steady state simulation, in which Century was integrated using global climatology, soils, and vegetation descriptions as described above. That simulation was carried out according to the protocols of the Potsdam Intercomparison of the IGBP Global Analysis, Interpretation, and Modeling (GAIM) Task Force [see Cramer et al., 1995].

Second, we carried out a temperature anomaly experiment on a globally distributed subset of grid cells in which we modified the temperatures based on the deviations from long-term averages that occurred over the period 1981-1994. The devia- 


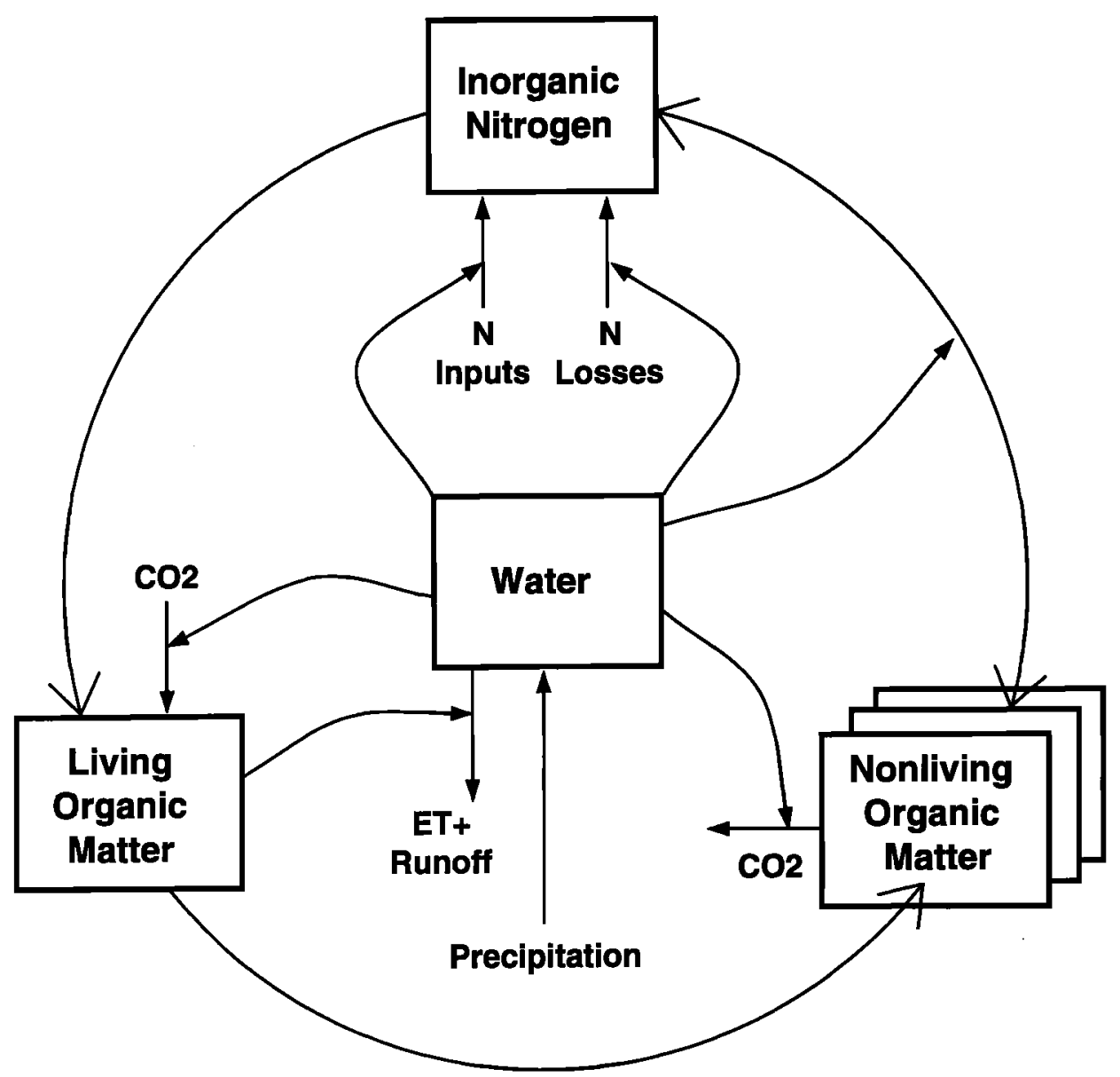

Figure 2. The cyclic coupling of carbon, water flux, and nitrogen cycle processes, idealized from Century. Critical points include the control of the nitrogen budget by the hydrological cycle, the feedbacks between carbon and water dynamics, and the effect of carbon flux on the capture of nitrogen into organic forms.

tions or "anomalies" were based on satellite measurements using the microwave sounding unit (MSU) aboard the National Oceanic and Atmospheric Administration polar orbiting spacecraft [Spencer et al., 1990]. The long-term monthly means were subtracted from each monthly value to create an anomaly time series with mean zero. The deviations were added to or subtracted from the climatological values. The MSU temperatures are for the lower troposphere and so are not precisely the same as surface temperatures, although the anomalies are usually highly correlated. Monthly precipitation was held constant at climatological values in this simulation. Because surface observations in high latitudes are very sparse, the satellite-based approach has significant advantages. The satellite temperatures are global measurements and avoid the problems of interpolation from station data. As will be seen, temperature anomalies in the northern hemisphere high latitudes are quite significant.

Third, we carried out a temperature perturbation experiment. At a subset of sites, we integrated the model to quasi-steady state and then perturbed the model by increasing monthly temperatures by 3 standard deviations over a period of either 1 or 5 years and then returned temperatures to their long-term mean. The model integration was then continued for 3 additional decades. This experiment was carried out to determine the timescales of response to physical forcing and to aid in the interpretation of the temperature anomaly experiment described above.

\section{Results and Discussion}

\section{Nutrient and Water Limitation Equilibration at Steady State}

The water-carbon-nutrient relationships in Century emerge from its basic logic (see (1)-(5) above). In Century, the modeled fluxes of nitrogen through ecosystems are strongly influenced by the hydrological cycle. Inputs of $\mathbf{N}$ are either directly linked to precipitation (wet deposition) or assumed to be correlated with annual evapotranspiration (nitrogen fixation) as discussed above. Losses of nitrogen are similarly controlled by water. Leaching losses of $\mathrm{NO}_{3}^{-}$and dissolved organic $\mathrm{N}(\mathrm{DON})$ are directly controlled by the product of water flux and $\mathrm{NO}_{3}^{-} / \mathrm{DON}$ concentrations [Parton et al., 1994]. Losses of $\mathrm{N}$ trace gases are linked to mineralization of $\mathrm{NH}_{4}^{+}$ and $\mathrm{NO}_{3}^{-}$from organic matter. The rate of loss is controlled by an abiotic decomposition factor that increases as temperature, rainfall, and soil moisture increase [Parton et al., 1994; 
a
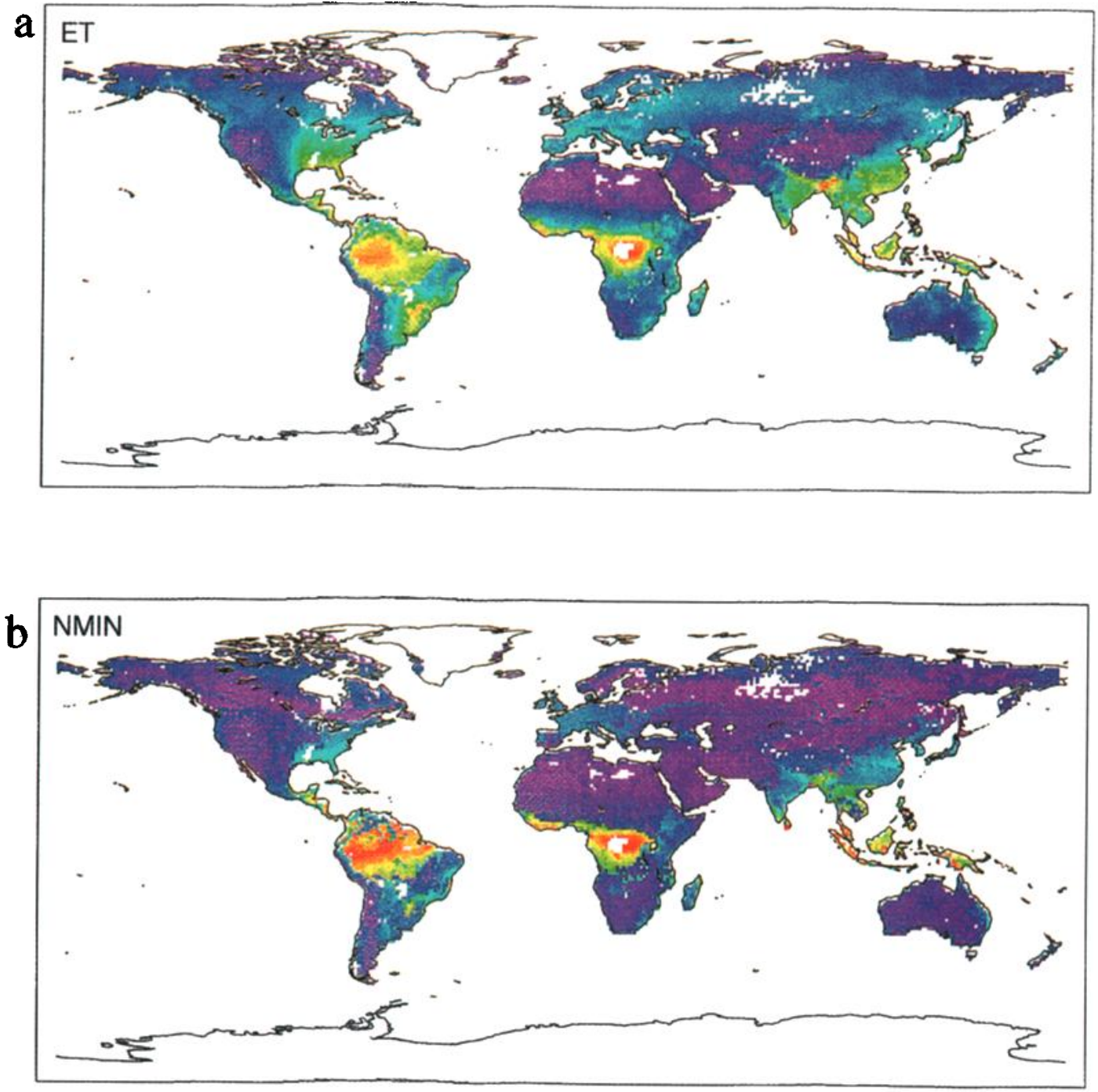

c

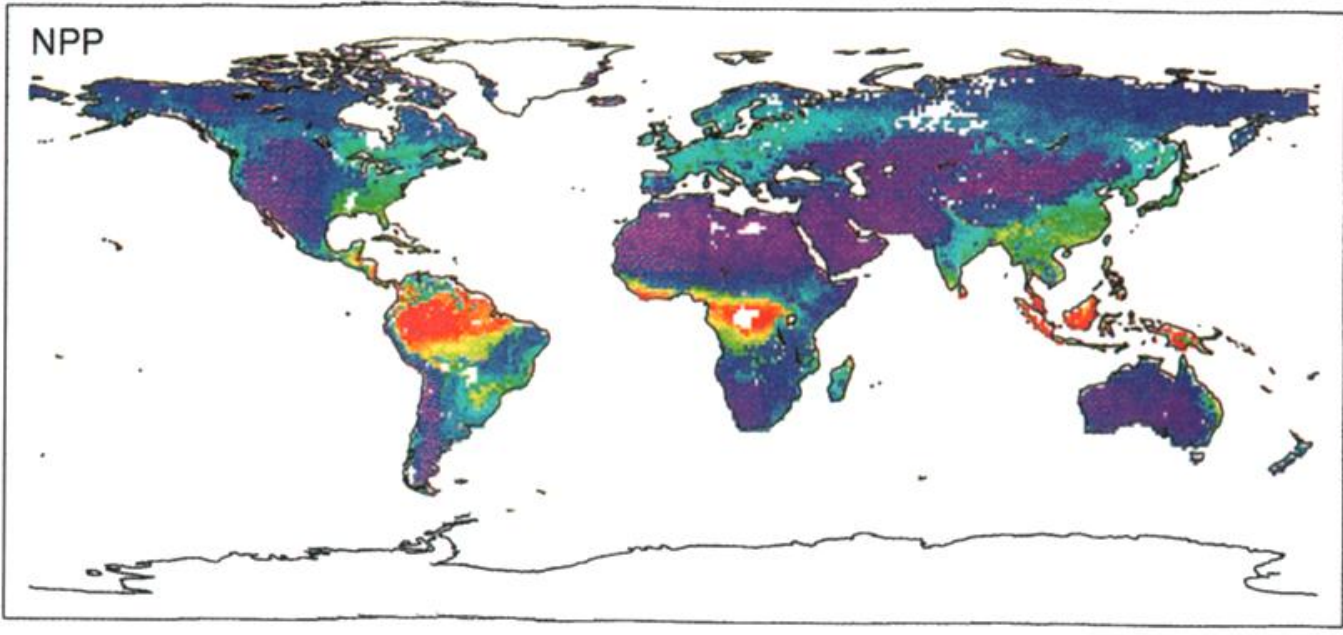

Plate 1. (a) Mapped annual evapotranspiration (ET) from a global steady state integration of Century. (b) Mapped nitrogen mineralization (the net production of $\mathrm{NO}_{3}+\mathrm{NH}_{4}$ from organic matter). (c) Mapped net primary production (NPP). 

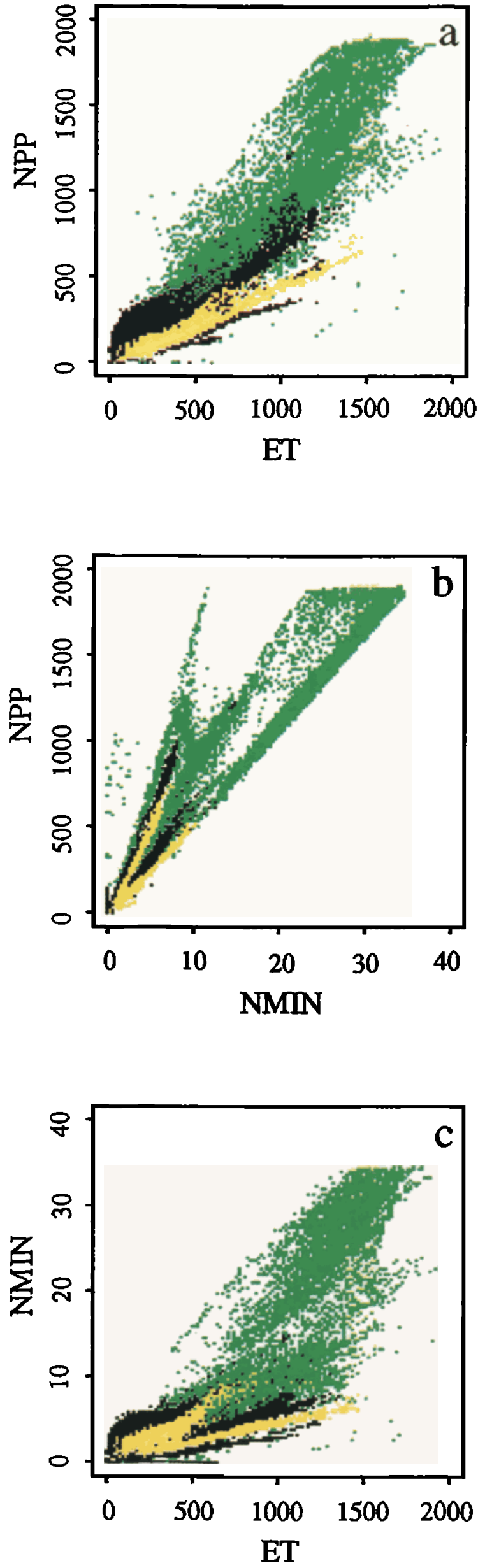

Holland et al., 1995]. Losses of gaseous $\mathrm{N}$ from inorganic $\mathrm{N}$ (proportional as well as absolute) also increase with increasing soil moisture [Parton et al., 1988]. Thus the flux of $\mathbf{N}$ through ecosystems will in general increase as precipitation increases. Critical controls over soil moisture and water flux through the soil include the atmospheric demand for water in evapotranspiration and the water holding capacity of soils Thus, although we argue that the hydrological cycle is a major control over $\mathrm{N}$ cycling, implicitly both energy (as a driving force for ET) and soil hydrological properties substantially modify the operation of the hydrological cycle from grid cell to grid cell.

Potential primary production increases as evapotranspiration increases in Century because the model includes an equation that constrains primary production by linking the sum of rainfall and previously stored water (divided by potential evapotranspiration) to production (equation (1)) [Parton et al., 1994]. This equation integrates the precipitation, energy and soil hydrological constraints over the evapotranspiration flux. Additionally, primary production requires nitrogen to form organic matter meeting critical $\mathrm{C} \mathrm{N}$ ratios for wood, foliage, and roots (equations (2) and (3)).

$\mathrm{N}$ is derived from precipitation and $\mathrm{N}$ fixation on centennial timescales, but on an annual timescale, most plant-available $\mathrm{N}$ is derived from nitrogen mineralization, which arises from the turnover of dead organic matter (decomposition). To illustrate the timescales of the $\mathrm{N}$ cycle, consider that nitrogen inputs range from $10-30 \%$ of $\mathrm{N}$ mineralization. $\mathrm{N}$ mineralization, in turn, averages $<5 \%$ of soil organic $N$. N mineralization is derived from the turnover of compartments with turnover times from 1-8 years $(-80 \%)$ and $30-90$ years $(-20 \%)$ [Schimel et al., 1994]. $\mathrm{N}$ losses due to trace gas emission and leaching range from $5 \%$ to $40 \%$ of inputs. Episodic losses due to fire and tree mortality, averaged over the modeled disturbance cycle, bring losses to near equality with inputs. Because inputs range from 0.4-1.5 $\mathrm{g} \mathrm{N} \mathrm{m}^{-2} \mathrm{yr}^{-1}$ and soil nitrogen levels typically exceed $500 \mathrm{~g} \mathrm{~N} \mathrm{~m}^{-2}$, $\mathrm{N}$ storage can only increase at a fraction of a percent per year even if losses are zero.

The structure of the model results in cyclic coupling of production and decomposition during the approach to steady state (Figure 2). Forest NPP in Century approaches a constant value as the nitrogen budget approaches balance (inputs equal to outputs). However, when NPP stabilizes, net ecosystem production (NEP) may still be small and positive in forests, because of the continuing accumulation of carbon in wood with minimal requirements for additional nitrogen, which are met by small changes in storage or nitrogen use efficiency. Thus, for forests, Century simulates a quasi-steady state.

As water flux increases, $\mathbf{N}$ flux increases, and likewise, the potential for carbon fixation increases. As carbon fixation increases, the amount of the $\mathrm{N}$ flux that can be captured in organic matter increases. As more nitrogen is captured in organic matter, its subsequent turnover also contributes to

Plate 2. (a) The relationship between NPP and ET, from Plates $1 \mathrm{a}$ and $1 \mathrm{~b}\left(\mathrm{R}^{2}=0.86\right)$. (b) The relationship between $N$ mineralization and NPP, from Plates $1 b$ and $1 c\left(R^{2}=0.92\right)$, (c) The relationship between $N$ mineralization and ET, from Plates la and $1 c\left(R^{2}=0.75\right)$. Green indicates forest, black indicates savanna, and yellow indicates grassland 


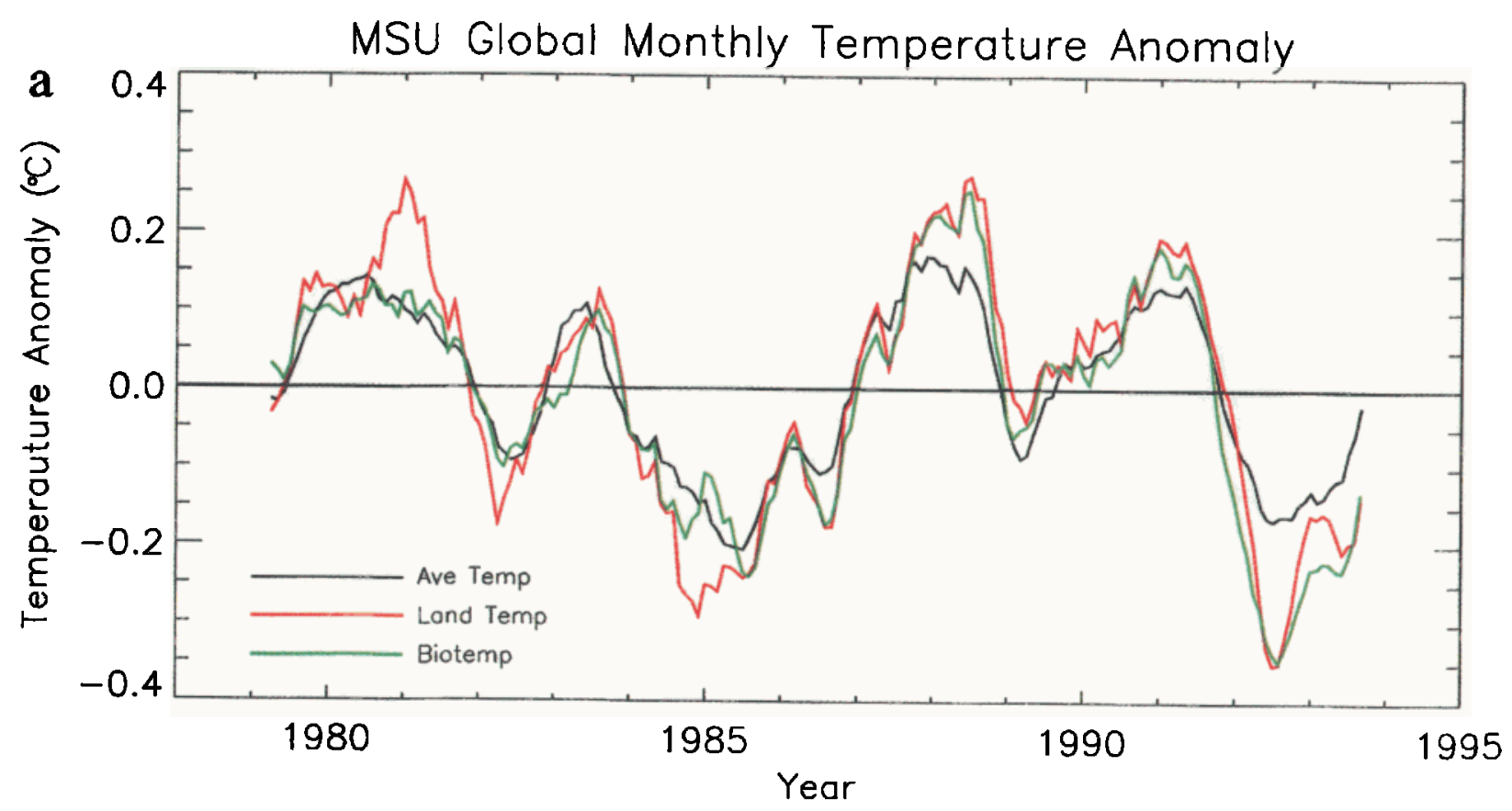

MSU Temperature Difference 1992-Ave (JJA)

b

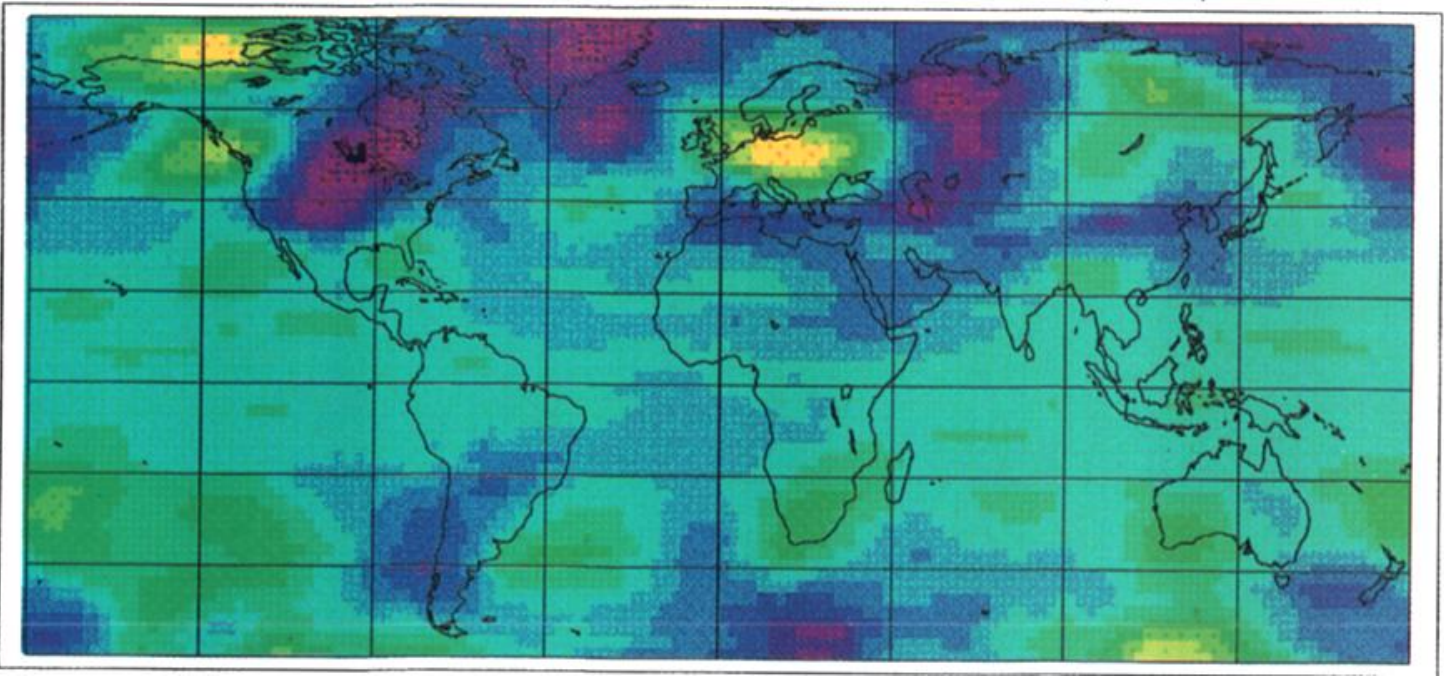

Plate 3. (a) Temperature anomalies from the microwave sounding unit, showing the global average, the average over land, and the average over land during the northern hemisphere summer (biotemp: June, July, and August (JJA)). (b) The spatial distribution of the boreal growing season temperature anomalies following Pinatubo (JJA 1992 $^{-} \mathrm{JJA}_{\mathbf{2 v e}}$ ).

plant-available $\mathrm{N}$, allowing more plant productivity. These processes contribute to accumulation of living and nonliving organic matter reflecting the water budget. Plates 1a-1c show the global distribution of modeled NPP, ET, and nitrogen mineralization. Strong correlations between ET, nitrogen availability, and net primary productivity appear in global steady state simulations (Plates 2a-2c). The relationships amongst ET, $\mathrm{N}$ mineralization, and NPP are modulated on a grid cell-to-grid cell basis by other factors that influence turnover times, such as temperature, ecosystem type-specific factors that control resource use efficiencies (effectively the carbon- to-nutrient stoichiometry of plants and microorganisms), and water use efficiency (organic matter produced per unit water transpired). ET itself is also influenced by physical soll and energy budget variables that influence the partitioning of precipitation to transpiration, evaporation, and runoff, with consequent effects on water use efficiency.

Whereas large-scale patterns in NPP-resource relationships arise from system-level interactions of the biogeochemical and hydrological cycles, substantial variation is induced by species- and growth form-specific traits. The correlation of variables in Plates 2a-2c indicates the extent to which NPP and 
nitrogen cycling are controlled by system-level dynamics: the scatter and variability of slopes indicate roughly the extent to which system-specific ecological traits influence NPP and nitrogen cycling.

The relationships in Plates 2a-2c appear as trends, with different slopes and/or intercepts for different ecosystem types, rather than as unitary relationships. Although each of the biome types used in parameterizing global Century have specific resource use efficiencies, it is apparent that some large-scale patterns exist between forests, grasslands, and mixed ecosystem types, such as savannas. Systems with woody components have higher $\mathbf{N}$ use efficiencies (NPP vs. $N_{\min }$ ) (see, for example, Plate $2 b$ ), as do $C_{4}$ compared to $C_{3}$ photosynthetic pathway grasslands. Savannas that have both woody and herbaceous components show $\mathrm{N}$ mineralizationNPP relationships similar to but slightly higher than grasslands, Within savannas, a similar bifurcation is observed, reflecting the differentiation between savannas with $C_{3}$ versus $C_{4}$ grass understories. $A_{3}-C_{4}$ effect is also observed in the $\mathrm{N}$ mineralization-ET relationship. In this case, differences in nitrogen use efficiency between $C_{3}$ and $C_{4}$ grasses result in changes to detrital $\mathrm{C}: \mathrm{N}$ ratios that in turn influence $\mathbf{N}$ mineralization.

Water use efficiency (NPP per unit ET) increases as the fraction of woody biomass increases (Plates 2a-2c). This pattern reflects the use of ET rather than transpiration in these Plates (2a-2c). The modeled ratio of evaporation to transpiration generally increases from forests to grasslands in Century and produces part of this pattern. Also, although grasses, especially $C_{4}$ grasses, have high photosynthetic water use efficiency, Century predicts that the fraction of photosynthate translated into NPP increases as the nitrogen demand of new tissue decreases. Thus systems dominated by woody tissue have higher effective water use efficiencies at the annual timescale than grasslands because of $\mathrm{N}$ constraints on the production of high-N foliar tissue in grasslands. This is amplified by higher absolute rates of $\mathrm{N}$ cycling in humid forest ecosystems compared to grasslands (Plate 1b). The interaction of water and nitrogen use efficiencies in Century is consistent with the biogeochemical orientation of the model [VEMAP Members, 1995; Schimel et al., 1996] and suggests that model comparisons with annual timescale observations of water and nitrogen use efficiencies between grasslands, savannas, and forests, as can be derived from some flux experiments [Wofsy et al., 1993], are crucial for model testing.

There are limited observations to support the hypothesis of tripartite correlation amongst N, water flux, and NPP, but Zak et al. [1994] report correlations amongst an index of nitrogen availability, aboveground NPP, and ET. The model results are also consistent with observations of large-scale correlations of NPP with direct or derived climate variables and also with experimental evidence of nutrient limitation. This result is consistent with the argument of Pastor and Post [1993, p. 115] that the Rosenzweig [1968] relationship of NPP to actual evapotranspiration was a "steady state consequence of the interactions between species and soil nitrogen and light availabilities as constrained by temperature and soil water deficits," and not a "...direct relationship between actual evapotranspiration and productivity." The modulation of the water-carbon-nitrogen system by species- and/or growth formspecific traits implies that large-scale dynamics are influenced by population dynamics on timescales longer than the life spans of individual plants (years-centuries).

Because of the sensitivity of Century to resource use efficiency and allocation patterns, a knowledge of the spatial and temporal distributions of physiological traits (either for species or functional plant types) is critical for modeling biogeochemistry. Knowledge of how these traits might change with adaptation, evolution, or migration is critical in the long run for predictive or retrospective analyses on timescales commensurate with ecosystem type change [Bolker et al., 1995].

\section{Temperature Anomalies}

Temperature variability (Plates $3 a, 3 b$ ) causes biogeochemical responses in the Century model. In the temperature
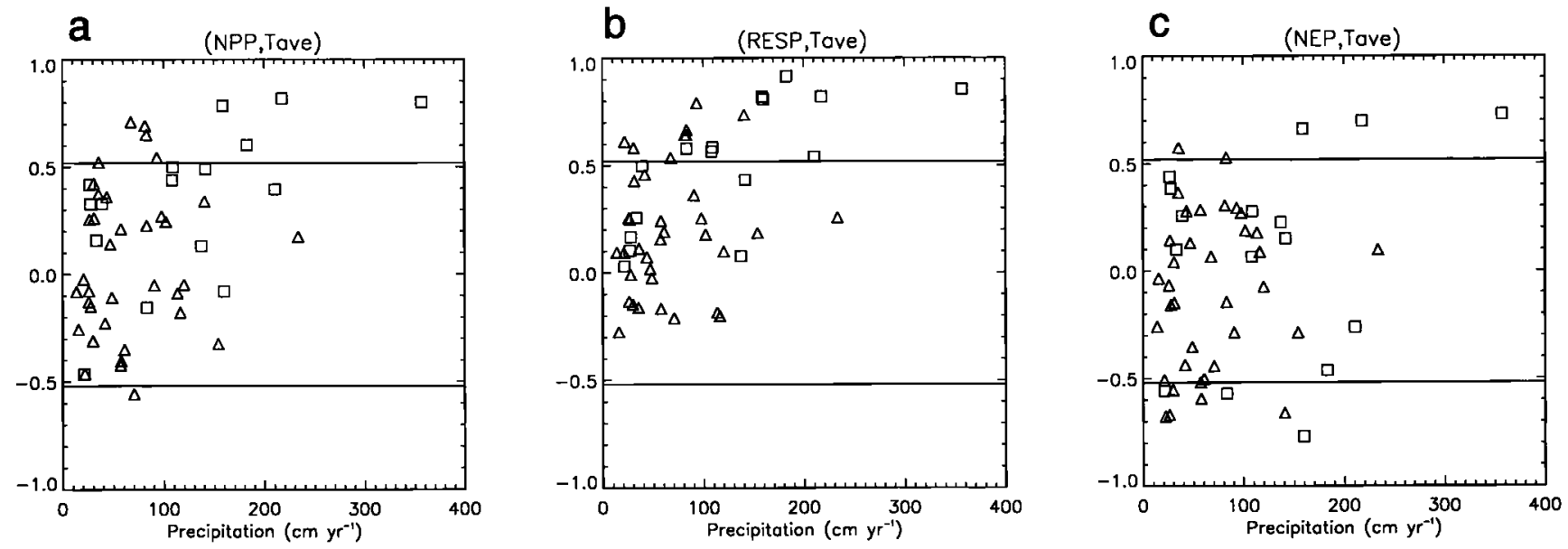

Figure 3. (a) Correlations for 52 grid cells between temperature and NPP anomalies, plotted against precipitation. (b) Correlations for $\mathbf{5 2}$ grid cells between temperature and heterotrophic (microbial) respiration anomalies, plotted against precipitation. (c) Correlations for 52 grid cells between temperature and NEP anomalies, plotted against precipitation. Horizontal lines show $95 \%$ confidence intervals for Rs significantly different from zero. Squares represent forest sites, and triangles represent grassland sites. 
anomaly experiment, highly variable correlations over time between NPP, respiration, and NEP with temperature were observed (Figures 3a-3c). The correlations with temperature tended to be higher as precipitation increased. In systems where water is strongly limiting to NPP, interannual variations in temperature have comparatively little effect. Conversely, we would expect such systems to be very responsive to interannual variations in precipitation [Parton et al., 1995]. The lack of response to temperature is surprising. Temperature is a direct driver of biogeochemical processes in Century, and one would expect a fairly direct correlation between temperature anomalies and resulting biogeochemical anomalies. In fact, the correlations are not always high (only a small number of the correlations in Figures $3 a-3 c$ are significantly different from zero at a $95 \%$ level), and the proportionality between changing temperature and changing biogeochemical response was highly variable. This occurs because of lagged effects of temperature via water budget and biogeochemical mechanisms explored in the next section.

One of the dramatic carbon cycle phenomena during the 1990s was the reduction in the growth rate of $\mathrm{CO}_{2}$ in 1992 , following the eruption of Mount Pinatubo in the Philippines and the consequent cooling due to stratospheric aerosols [Hansen et al., 1992; Ciais et al., 1995b; Francey et al., 1995; Keeling et al., 1995; Schimel, 1995]. The effect of the Pinatubo eruption was a reduction in the growth rate of $\mathrm{CO}_{2}$, corresponding to an anomalous or additional uptake of $\mathrm{CO}_{2}$ of about 2 Gt. Isotopic evidence suggested a terrestrial rather than marine sink [Keeling et al., 1995; Ciais et al., 1995b]. The MSU temperatures capture the Pinatubo cooling clearly (Plates $3 a, 3 b)$ and show it to have significant spatial structure, concentrated in the northern hemisphere. Coolings during the boreal growing season of up to $3^{\circ} \mathrm{C}$ are evident (Plate $3 \mathrm{~b}$ ). Despite the complexity of the temperature response of Century, the model predicts significant increases in per-unit- area NEP in midlatitudes $\left(30^{\circ}-60^{\circ} \mathrm{N}\right)$. The model predicts release of $\mathrm{CO}_{2}$ from high latitude regions (negative NEP), but there is comparatively little biologically active land area in that latitude band. If the predicted average NEP of $+30 \mathrm{~g} \mathrm{~m}^{-2}$ was representative of the $30^{\circ}-60^{\circ} \mathrm{N}$ region (Figure 4), that could easily amount to 1-3 Gt C globally. Thus the Century model results are consistent with a Pinatubo-related anomalous increase in NEP (arising mostly from reduced respiration rather than increased NPP) of magnitude comparable to the additional sinks deduced from observations. If the modeled responses to the cooling are correct, an overshoot in atmospheric $\mathrm{CO}_{2}$ should occur as the short-lived carbon pools, whose size increased during the cooling, relax back to equilibrium with warmer temperatures. However, because of the low and variable direct correlations between temperature and ecosystem processes, we propose a more complex hypothesis for the observed and simulated Pinatubo effect below.

\section{Temperature Perturbations and Timescales}

Although biophysical and nutrient limitations of NPP tend to equilibrate with each other (Plates 2a-2c); [Schimel et al., 1996], the equilibration will not be instantaneous. The response times of the different carbon-water-nitrogen components of ecosystems are not identical, and some are long. It requires years for soil water, decomposition, and nitrogen cycling to return to steady state after a perturbation because of inherent lags in the system. We carried out a simple simulation experiment in which we increased air temperatures each month by 3 standard deviations for the duration of either 1 or 5 years to probe the lagged responses suggested by the temperature anomaly experiment. Figure 5a shows the response for a northern boreal forest. NPP increases during the year of the perturbation because of a longer growing season and reduced temperature stress. Respiration (decomposition) decreases because warmer winter temperatures lead to reduced soil water

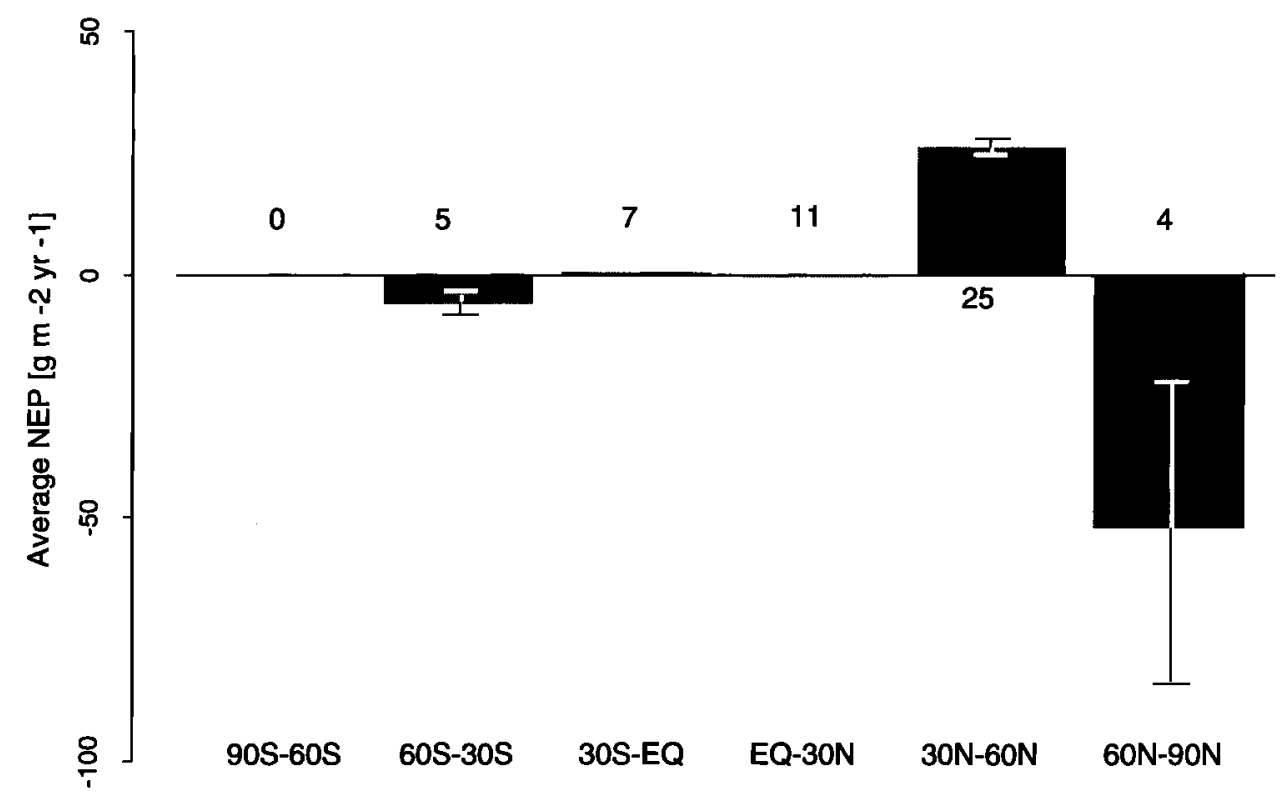

Figure 4. The effects of the Pinatubo temperature anomaly on net ecosystem production for 52 gridcells, averaged zonally. Error bars indicate mean \pm one standard error. 
a.
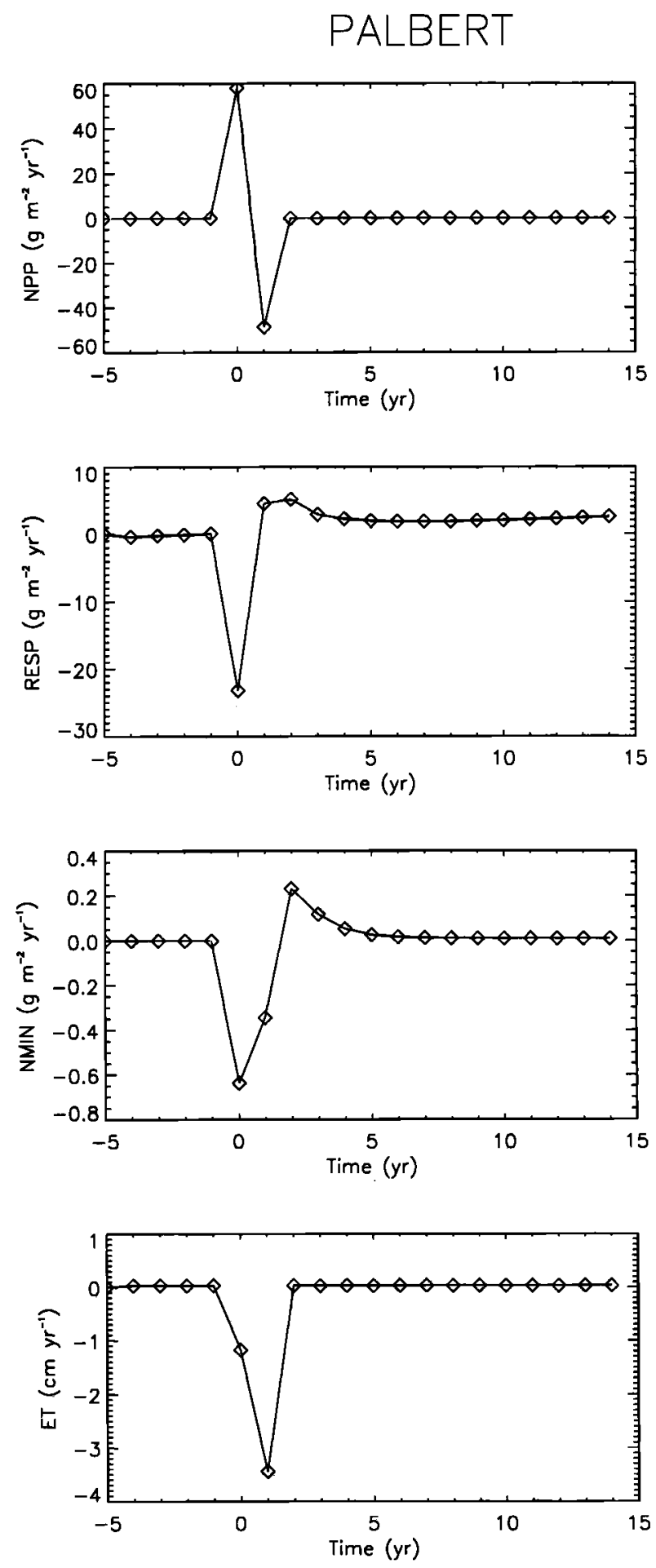

b.
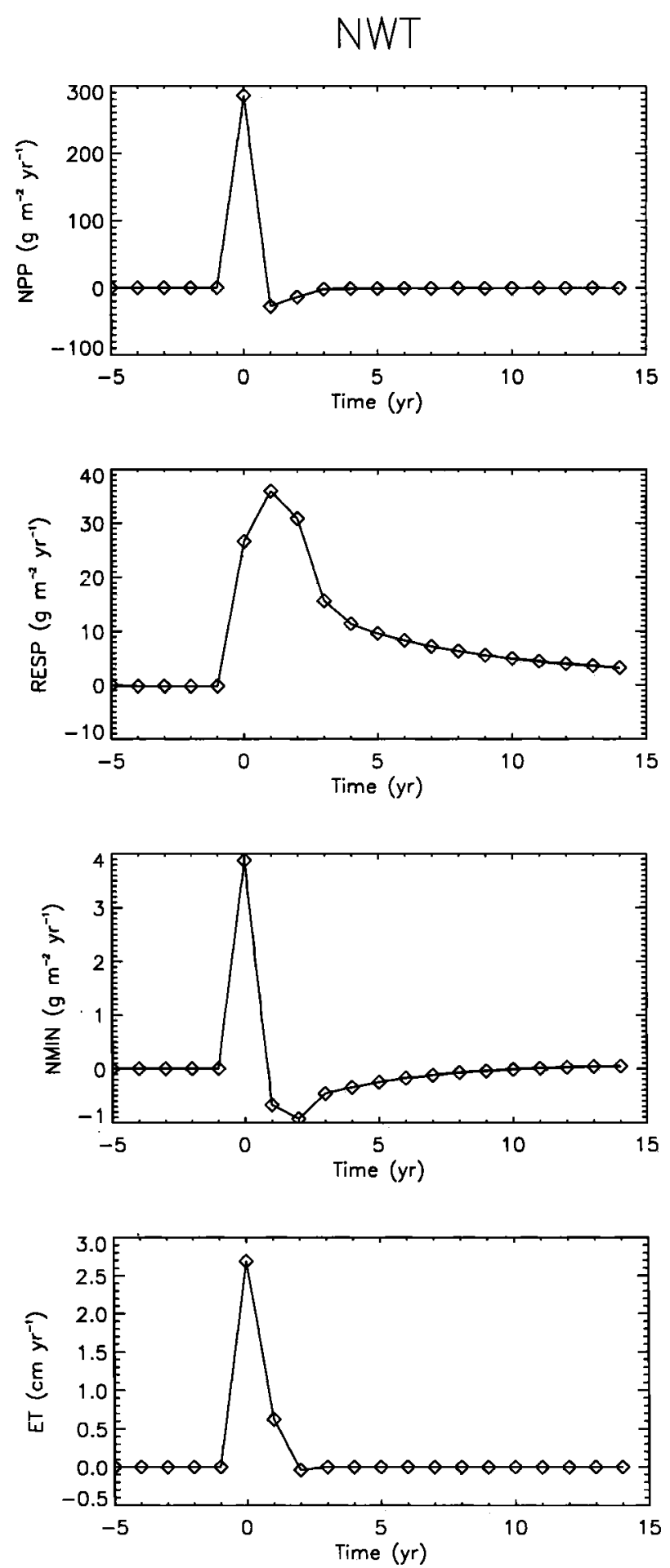

Figure 5. Results from a perturbation experiment in which the model, after integration to steady state, was perturbed by a 1-year warming by increasing each month's temperature by 3 standard deviations. (a) NPP, microbial respiration (decomposition), nitrogen mineralization, and ET (top to bottom) for a northern boreal forest grid cell. (b) As in Figure 5a, but for an alpine tundra grid cell. Results are shown as deviations from steady state values. 
a.
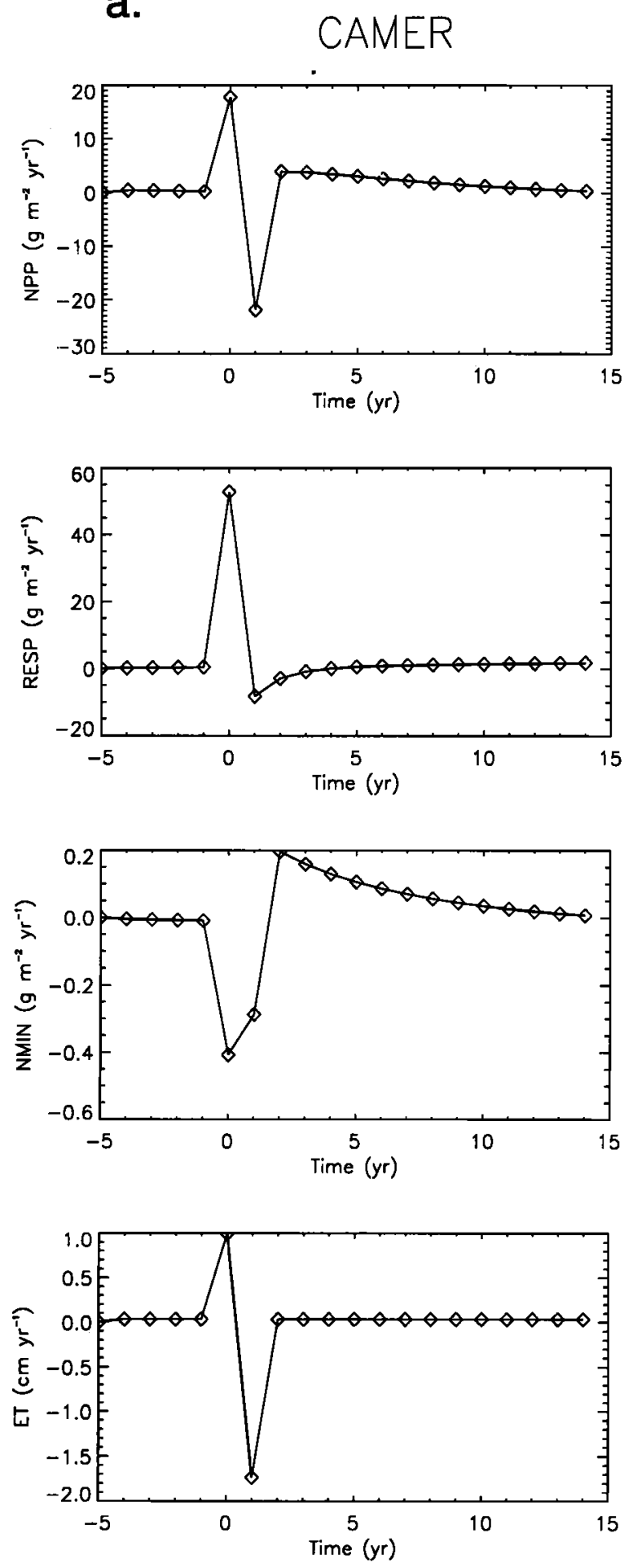

b.
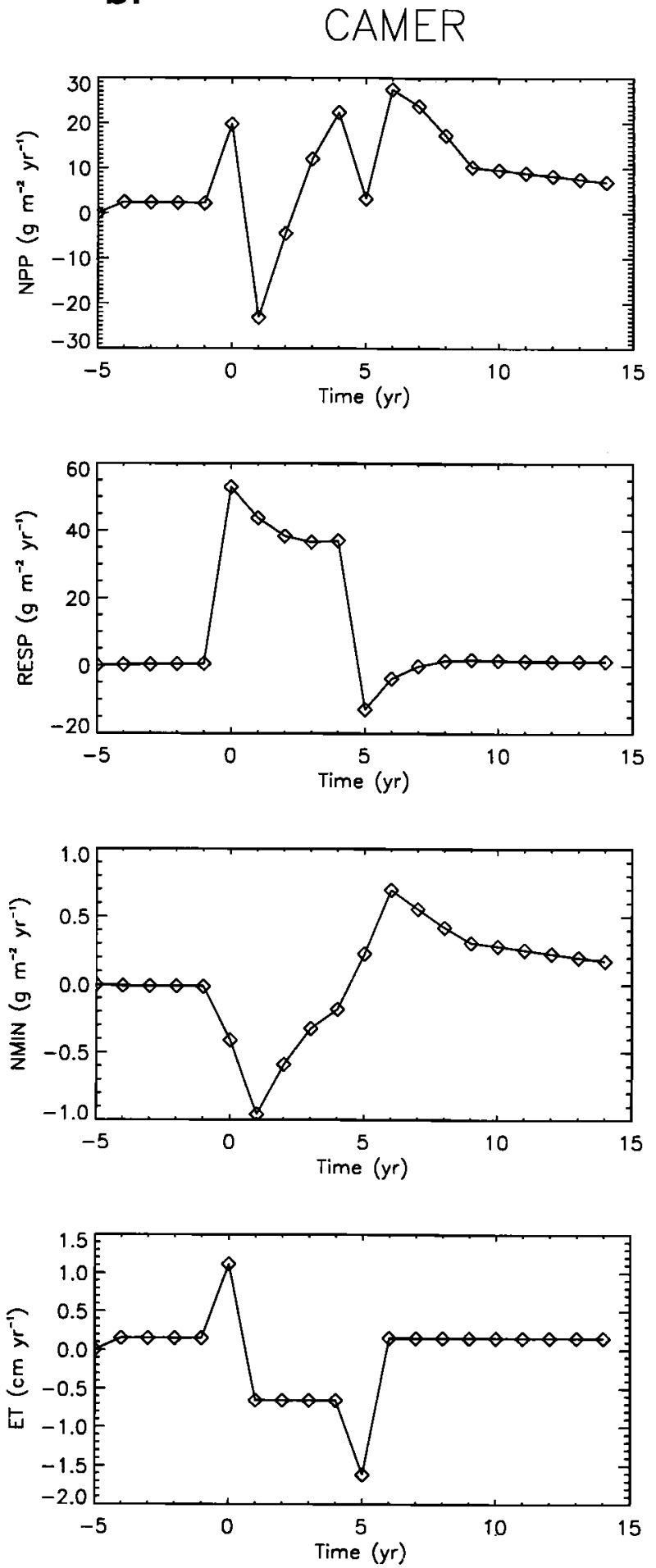

Figure 6. (a) As in Figure 5, but for a tropical forest grid cell. (b) Using the same grid cell as Figure 6a, but showing results for NPP, respiration, nitrogen mineralization, and ET following a 5-year temperature perturbation.

(more evaporation from snow), reducing ET. $\mathrm{N}$ mineralization decreases, reducing NPP in the year following the perturbation. This occurs because of increased litterfall (from the enhanced NPP), and thus more microbial competition for $\mathrm{N}$, and because of dryer soils. Soil water is affected by the perturbation both directly and through the increased water demand associated with the initial increase in NPP and returns to steady state after 3 years. The additional detritus resulting from the initial rise in NPP increases respiration beginning in year 2 and also leads to increases in both $\mathbf{N}$ mineralization and respiration that persist for years.

Figure 5b shows an alpine tundra site in which warming 
increases N mineralization, NPP, and ET. Increased NPP leads to increased respiration that persists for $>15$ years (because of slow decomposition in this cold, short growing season site), affecting net ecosystem production (NEP = NPP - heterotrophic respiration) for decades. Tropical sites (Figure 6a) show similar lags, modulated by the water cycle. Respiration equilibrates rapidly because of high decomposition rates due to warm temperatures. When the temperature perturbation lasts for 5 years, complex behavior occurs as the system responds to the initial perturbation, equilibrates to the changed temperatures, and then responds again in a transient manner to the cessation of the temperature perturbation (Figure $6 \mathrm{~b}$ ). Whereas the sites examined in Figures 5 and 6 show NPP responses of opposite sign in the year of and following the perturbation, this is a frequent but not invariable behavior of the model. Other sites show large initial responses with monotonic returns to steady state, on timescales linked to component response times [Schimel et al., 1994].

The above responses were controlled by iterative feedbacks between the water, carbon, and nitrogen cycles, leading to complex responses on annual-to-decadal timescales. The responses were system-specific and were influenced by the initial steady state. In particular, systems in which precipitation often exceeds ET and in which stored soil moisture is significant are sensitive to perturbations and may have multiyear responses to perturbations through the water cycle. The temperature perturbation experiment helps explain why the instantaneous correlations shown in Figure 3 between temperature and ecosystem processes are low.

The experiments reported in this paper, taken together, suggest the hypothesis that the Pinatubo effect resulted from both the instantaneous effect of cooling on metabolism and the water and nutrient status of ecosystems prior to the cooling. For each site simulated, water and nutrient limitation at each time step reflected the preceding pattern of temperature anomalies and the lags specific to the ecosystem type being simulated. Thus the Pinatubo anomaly reflected the history of temperature anomalies over the previous decade, as well as the instantaneous effect of the cooling. Global simulations with climate perturbations based on observed anomalies are now in progress to determine the broad-scale patterns that emerge from the complex site-specific responses [Braswell et al., 1995].

The modeled NEP perturbations from the temperature perturbation experiments range from $5 \%$ to $20 \%$ of steady state NPP. If spatially coherent anomalies in climate produced responses of this magnitude, then global anomalies in the terrestrial carbon balance resulting from interannual climate variability could easily be of the order of several Gt C (assuming that global NPP is 40-60 Gt C [Schimel et al., 1995]). Carbon anomalies in the 1-3 years following a climate anomaly could be as large as or larger and of opposite sign from the initial response, leading to the low time series correlations of temperature and biogeochemical anomalies observed in the temperature anomaly experiment. Changes of $5 \%$ to $20 \%$ of NPP are, however, extremely difficult to detect given sampling variability using conventional techniques, and so observational detection will require care with methodology [Parton et al., 1995].

\section{Role of Lagged Effects in the Global Carbon Cycle}

Several groups have attempted to quantify the effects of climate anomalies on terrestrial carbon storage using models compared to global $\mathrm{CO}_{2}$ observations. These efforts have often included the assumption that the effects of anomalous temperature and precipitation are instantaneous and have no lagged effects [e.g., Dai and Fung, 1993]. Other approaches cannot diagnose the mechanisms underlying any lagged effects because they use satellite observations (modified by climate data) to estimate NPP (although lags may be present in the satellite observations [Potter et al., 1993; Thompson et al., 1995]). Observational time series studies suggest lagged effects. For example, the Mount Pinatubo eruption appears to have caused an anomalous increase in terrestrial carbon uptake, apparent as a decrease in the growth rate of atmospheric $\mathrm{CO}_{2}$ [Braswell et al., 1995; Ciais et al., 1995a, b; Keeling et al., 1995; Schimel, 1995]. This decrease in the growth rate, however, began before the eruption. Keeling et al. [1995] have speculated this may be a rebound from the warm years of the late 1980 s, which may have been reinforced by the Pinatubo cooling, behavior that is qualitatively consistent with some site-specific Century simulations. The direct post-Pinatubo effect may have occurred because of reductions in respiration with cooler temperatures that were larger than the decreases in NPP [Braswell et al., 1995]. Keeling and colleagues have also suggested that, on decadal timescales, warming causes increases in terrestrial carbon uptake but with a 2-year lag [Keeling et al., 1995]. This is a response consistent with a nutrient release-controlled response but not obviously with a Dai and Fung [1993] type of instantaneous physiological response of plants and decomposers. Because of the individualistic responses of the sites simulated in this study, we cannot yet determine whether Century's response is qualitatively consistent with Keeling et al.'s [1995] analyses, but the existence of significant lags in the model is a precondition for more comprehensive agreement.

Investigation of mechanisms leading to long-term equilibration and perturbation responses will increase understanding of processes tied to the "slow" components of ecosystems (woody biomass, detritus, and soil organic matter), processes that are difficult to study with experimental techniques. Such investigation will provide a crucial window into the components of terrestrial ecosystems that may govern long-term responses to changing climate, $\mathrm{CO}_{2}$, and other perturbations (e.g., $\mathrm{N}$ deposition [Townsend et al., 1996]). Hedin et al. [1995], for example, suggest profound and longlived effects of anthropogenic perturbations to nitrogen deposition. Ecosystem $\mathbf{N}$ inputs (deposition and biological $\mathbf{N}$ fixation) are not well known for much of the world, nor are they understood mechanistically. $\mathbf{N}$ outputs are likewise not well quantified globally [Hedin et al., 1995].

\section{Conclusions}

We hypothesize that water and nitrogen limitations of NPP are correlated at steady state because of the equilibration of water and nitrogen limitation of NPP that occurs through the 
control of carbon and nitrogen fluxes by the water budget. We further hypothesize that these correlations arise because of the structure of interactions amongst the water, carbon, and nitrogen cycles: they are a system-level property. As a corollary, ecological differences in resource use efficiencies, soil properties, and temperature should induce substantial quantitative variability in the water-nitrogen-carbon relationships, requiring that, eventually, community and biogeographic processes be integrated into biogeochemical models. Many of the steady state patterns in Century arise through simulation of the nitrogen budget, rather than as a result of internal cycling. This is a unique feature of Century and allows the mechanisms under-lying resource interactions to be diagnosed explicitly. Most other current ecosystem models initialize $\mathrm{N}$ stocks based on observations [Potter et al., 1993], or iteratively, to force consistency with observed or assumed fluxes [Melillo et al., 1993].

These hypotheses and corollary are consistent with recent regional [Schimel et al., 1996] and global model results and some data but require additional testing. Further, because the water, nitrogen, and carbon budgets respond to perturbation on different timescales, the responses of ET, nitrogen availability, and NPP during transient climate changes are not necessarily tightly correlated. Interannual variability in the terrestrial carbon cycle, as inferred from $\mathrm{CO}_{2}$ observations, may arise from complex multiyear causes, and this complex behavior may become more evident as the spatial resolution and continental focus of atmospheric $\mathrm{CO}_{2}$ observations increases. Although Century suggests that the Mount Pinatubo cooling could have caused a significant shift in terrestrial carbon exchange, consistent with observations, it also suggests that this effect was manifest through temperature effects on water relations, leaf area changes, and nutrient cycling, rather than via a simple effect of temperature on metabolism. The model further suggests that through lagged effects the magnitude of interannual changes in biogeochemistry should reflect climate patterns over several preceding years.

To detect either systematic $\left(\mathrm{CO}_{2}\right.$-caused [Friedlingstein et al., 1995; Fung et al., 1995] or N-caused [Townsend et al., 1996]) or interannual changes, one must consider the possibility of lagged effects, and sampling designs and associated process studies should take into account both signal and noise arising from lagged changes to hydrological and biogeochemical processes [Fung et al., 1995]. Detection of patterns and processes associated with water budget and biogeochemical lags will provide a window on the slower processes in ecosystem metabolism that may dominate global change effects on ecosystems in the future.

Finally, experimental evaluation of global ecosystem models is difficult [Schimel et al., 1996]. Because the changes predicted for NPP, NEP, and respiration by the Century model are modest relative to local spatial sampling variability, observational validation will be difficult and may require careful multiyear monitoring with techniques insensitive to small-scale variability, such as flux measurements using aerodynamic techniques [Wofsy et al., 1993; Lenschow, 1995] or will require inverse estimates from concentration fields [e.g., Ciais et al., 1995a, b]. Experimental studies that directly probe the relevant mechanisms (i.e., by directly or indirectly changing transpiration, nitrogen availability, or carbon inputs via manipulative experiments) are critical; reexamination of existing studies of fertilization by $\mathrm{N}$ or $\mathrm{CO}_{2}$ may prove highly useful. Attribution of variation to specific mechanisms operating on multiple timescales will also require innovative measurements of nitrogen inputs, outputs, and internal cycling at large spatial scales.

Models with a wide range of formulations have all been able to reproduce observed variations in atmospheric $\mathrm{CO}_{2}$ or limited site-specific observations of NPP [e.g., Fung et al., 1987; Bonan, 1993; Potter et al., 1993; Schimel et al., 1996] approximately equally well. Because site-specific measurements, such as of NPP, have high uncertainty resulting from local heterogeneity, it is difficult to reject ecosystem models using such data. However, global-scale process models make some very specific predictions about ecosystem-type differences in resource use efficiency and other robust measures of ecosystem physiology. These may be tested at large spatial scales using flux measurement techniques supplemented by critical nitrogen measurements. Resource use efficiency diagnostics of model performance are less subject to tuning than is NPP and also provides insight into model behavior under altered environmental forcing [VEMAP Members, 1995]. This study suggests that data sets providing, at an annual timescale, measures of NPP and water and nitrogen use efficiencies from ecosystems ranging from grasslands through savannas to forests could be extremely powerful in testing ecosystem models.

Acknowledgments. We acknowledge the assistance of Melanie Hartman and Hank Fisher with conducting and analyzing global Century runs and Nan Rosenbloom for extraction of global temperature data. The IGBP GAIM Task Force and the Potsdam Institute for Climate Impacts are gratefully acknowledged for encouraging this study and for providing needed data sets. Pieter Tans suggested pursuing the Pinatubo effect using Century and provided access to MSU data; Elizabeth Sulzman helped with atmospheric $\mathrm{CO}_{2}$ growth rate data and with weaving together the various parts of this study. Thanks to Beth Holland, Alan Townsend, and Jason Neff who all helped conceive of or design the model experiments in a stimulating session at the Little Cottonwood Canyon campground. This research was supported by NASA's EOS Interdisciplinary Science Program and by NCAR. Support for B.H.B. was provided by the DOE/Oak Ridge Associated Universities' Graduate Fellowships for Global Change. The National Center for Atmospheric Research is sponsored by the National Science Foundation.

\section{References}

Bloom, A.J., F.S. Chapin III, and H.A. Mooney, Resource limitation in plants - An economic analogy, Ann. Rev. Ecol. Syst., 16, 363-393, 1985.

Bolker, B.M., S.W. Pacala, F.A. Bazzaz, C.D. Canham, and S.A. Levin, Species diversity and ecosystem response to carbon dioxide fertilization: Conclusions from a temperate forest model, Global Change Biol., 1, 373-381, 1995.

Bonan, G.B., Physiological derivation of the observed relationship between net primary production and mean annual air temperature, Tellus Ser. B, 45, 397-408, 1993.

Braswell, B.H., D.S. Schimel, D.S. Ojima, and P. Tans, Decadal-scale temperature anomalies and transient modeling of terrestrial ecosystem $\mathrm{CO}_{2}$ fluxes, paper presented at XXI General Assembly, Int. Union of Geod. and Geophys., Boulder, Colo., July 2-14, 1995.

Burke, I.C., T.G.F. Kittel, W.K. Lauenroth, P. Snook, C.M. Yonker, and W.J. Parton, Regional analysis of the central Great Plains, BioScience, 41, 685-692, 1991.

Chapin, III, F.S., A.J. Bloom, C.B. Field, and R.H. Waring, Plant responses to multiple environmental factors, BioScience, 37, 49-57, 1987. 
Ciais, P., P.P. Tans, J.W.C. White, M. Trolier, R.I. Francey, J.A. Berry, D.R. Randall, P.J. Sellers, J.G. Collatz, and D.S. Schimel, Partitioning of ocean and land uptake of $\mathrm{CO}_{2}$ as inferred by $\delta^{13} \mathrm{C}$ measurements from the NOAACClimate Monitoring and Diagnostics Laboratory Global Air Sampling Network, J. Geophys. Res., 100, 5051-5070, 1995a.

Ciais, P., P.P. Tans, M. Trolier, J.W.C. White, and R.J. Francey, A large northern hemisphere terrestrial $\mathrm{CO}_{2}$ sink indicated by ${ }^{13} \mathrm{C} /{ }^{12} \mathrm{C}$ of atmospheric $\mathrm{CO}_{2}$, Science, 269, 1098-1102, 1995b.

Cole, C.V., and R.D. Heil, Phosphorus effects on terrestrial nitrogen cycling, in Terrestrial Nitrogen Cycles, edited by F.E. Clark and T. Rosswall, pp. 363-374, Swed. Nat. Sci. Res. Counc., Stockholm, 1981.

Cramer, W., M. Claussen, and A.M. Solomon, An assessment of different climate change scenarios for the global redistribution of agricultural land, paper presented at First Scientific Conference, Int. Geosphere-Biosphere Programme, Global Anal., Interpret., and Model., Garmisch-Partenkirchen, Germany, Sept. 25-29, 1995.

Dai, A., and I.Y. Fung, Can climate variability contribute to the "missing" $\mathrm{CO}_{2}$ sink?, Global Biogeochem. Cycles, 7, 599-609, 1993.

Eisele, K.A., D.S. Schimel, L.A. Kapustka, and W.J. Parton, Effects of available $P$ and $N: P$ ratios on non-symbiotic dinitrogen fixation in tallgrass prairie soils, Oecologia, 79, 471-474, 1989.

Farquhar, G.D., S. Von Caemmerer, and J.A. Berry, A biochemical model of photosynthetic $\mathrm{CO}_{2}$ assimilation in leaves of $\mathrm{C}_{3}$ species, Planta, 149, 78-90, 1980.

Field, C.B., Ecological scaling of 'carbon gain to stress and resource availability, in Response of Plants to Multiple Stresses, edited by H.A. Mooney, W.E. Winner, and E.J. Pell, pp. 35-65, Academic, San Diego, Calif., 1991.

Francey, R.J., P.P. Tans, C.E. Allison, I.G. Enting, J.W.C. White, and M Trolier, Changes in oceanic and terrestrial carbon uptake since 1982, Nature, 373, 326-330, 1995.

Friedlingstein, P., I. Fung, E. Holland, J. John, G. Brasseur, D. Erickson, and $\mathrm{D}$. Schimel, On the contribution of $\mathrm{CO}_{2}$ fertilization to the missing biospheric sink, Global Biogeochem. Cycles, 9, 541-556, 1995.

Fung, I.Y., C.J. Tucker, and K.C. Prentice, Application of advanced very high resolution radiometer to study atmosphere-biosphere exchange of $\mathrm{CO}_{2}$, J. Geophys. Res., 92, 2999-3015, 1987.

Fung, I., P. Friedlingstein, and A. Dai, Atmosphere-biosphere $\mathrm{CO}_{2}$ exchanges for the past 200 years: Implications for a detection strategy, paper presented at First Scientific Conference, Int. Geosphere-Biosphere Programme, Global Anal., Interpret., and Model., Garmisch-Partenkirchen, Germany, Sept. 24-29, 1995.

Gifford, R.M., The global carbon cycle: A viewpoint on the missing sink, Aust. J. Plant Physiol, 21, 1-15, 1994.

Hansen, J., A. Lacis, R. Ruedy, and M. Sato, Potential climate impact of Mount Pinatubo eruption, Geophys. Res. Lett., 19, 215-218, 1992.

Hedin, L.O., J.J. Armesto, and A.H. Johnson, Patterns of nutrient loss from unpolluted, old-growth temperate forests: Evaluation of biogeochemical theory, Ecology, 76, 493-509, 1995.

Holland, E.A., A.R. Townsend, and P.M. Vitousek, Variability and temperature regulation of $\mathrm{CO}_{2}$ fluxes and $\mathrm{N}$ mineralization from five Hawaiian soils: Implication for a changing climate, Global Change Biol., 1, 115-124, 1995.

Ingestad, T., and A.B. Lund, Theory and technique for steady state mineral nutrition and growth of plants, Scand. J. For. Res., I, 439 453, 1986

Keeling, C.D., T.P. Whorf, M. Wahlen, and J. van der Plicht, Interannual extremes in the rate of rise of atmospheric carbon dioxide since 1980, Nature, 375, 666-670, 1995.

Lenschow, D.H., Micrometeorological techniques for measuring biosphere-atmosphere trace gas exchange, in Biogenic Trace Gases: Measuring Emissions from Soil and Water, edited by P.A. Matson and R.C. Harriss, pp. 126-163, Blackwell Sci., Cambridge, Mass., 1995.

Lieth, H., Primary production of the major vegetation units of the world, in Primary Productivity of the Biosphere, edited by H. Lieth and R.H. Whittaker, pp. 204-215, Springer-Verlag, New York, 1975.

Matson, P.A., and P.M. Vitousek, Cross-system comparisons of soil nitrogen transformations and nitrous oxjde flux in tropical forest ecosystems, Global Biogeochem. Cycles, 1, 163-170, 1987.

May, W., D.J. Shea, and R.A. Madden, The annual variation of surface temperatures over the world, NCAR Technical Note (TN - 372+STR) and NCAR Digital Data Set (DS513), 134 pp., National Center for Atmospheric Research, Boulder, CO, 1992.
Melillo, J.M., R.J. Naiman, J.D. Aber, and A.E. Linkins, Factors controlling mass loss and nitrogen dynamics of plant litter decaying in northern streams, Bull. Mar. Sci., 35, 341-356, 1984.

Melillo, J.M., A.D. McGuire, D.W. Kicklighter, B. Moore III, C.J. Vorosmarty, and A.L. Schloss, Global climate change and terrestrial net primary production, Nature, 363, 234-240, 1993.

Nobel, P.S., Physicochemical and Environmental Plant Physiology, 635 pp., Academic, San Diego, Calif., 1991.

Ojima, D.S., D.S. Schimel, W.J. Parton, and C.E. Owensby, Long- and short-term effects of fire on nitrogen cycling in tallgrass prairie, Biogeochemistry, 24, 67-84, 1994.

Parton, W.J., D.S. Schimel, C.V. Cole, and D.S. Ojima, Analysis of factors controlling soil organic matter levels in Great Plains grasslands, Soil Sci. Soc. Am. J., 51, 1173-1179, 1987.

Parton, W.J., J.W.B. Stewart, and C.V. Cole, Dynamics of C, N, P, and S in grassland soils: A model, Biogeochemistry, 5, 109-131, 1988.

Parton, W.J., et al., Observations and modeling of biomass and soil organic matter dynamics for the grassland biome worldwide, Global Biogeochem. Cycles, 7, 785-809, 1993.

Parton, W.J., D.S. Ojima, C.V. Cole, and D.S. Schimel, A general model for soil organic matter dynamics: Sensitivity to litter chemistry, texture and management, in Quantitative Modeling of Soil Forming Processes, edited by R.B. Bryant and R.W. Arnold, pp. 147-167, Soil Sci. Soc. Am., Madison, Wis., 1994.

Parton, W.J., J.M.O. Scurlock, D.S. Ojima, D.S. Schimel, D.O. Hall, and SCOPEGRAM Group Members, Impact of climate change on grassland production and soil carbon worldwide, Global Change Biol., l, 13-22, 1995.

Pastor, J., and W.M. Post, Linear regressions do not predict the transient responses of eastern North American forests to $\mathrm{CO}_{2}$-induced climate change, Clim. Change, 23, 111-119, 1993.

Post, W.M., J. Pastor, P.J. Zinke, and A.G. Stangenberger, Global patterns of soil nitrogen storage, Nature, 317, 613-616, 1985.

Potter, C.S., J.T. Randerson, C.B. Field, P.A. Matson, P.M. Vitousek, H.A. Mooney, and S.A. Klooster, Terrestrial ecosystem production: A process model based on global satellite and surface data, Global Biogeochem. Cycles, 7, 811-841, 1993.

Rosenzweig, M.L., Net primary productivity of terrestrial communities: Prediction from climatological data, Am. Nat., 102, 67-74, 1968.

Running, S.W., and E.R. Hunt Jr., Generalization of a forest ecosystem model for other biomes, BIOME-BGC, and an application for globalscale models, in Scaling Physiological Processes: Leaf to Globe, edited by J.R. Ehleringer and C.B. Field, Pp. 141-158, Academic, San Diego, Calif., 1993.

Running, S.W., and R.R. Nemani, Regional hydrolic and carbon balance responses of forests resulting from potential climate change, Clim. Change, 19, 349-368, 1991.

Sala, O.E., W.J. Parton, L.A. Joyce, and W.K. Lauenroth, Primary production of the central grasslands region of the United States: Spatial pattern and major controls, Ecology, 69, 40-45, 1988.

Schimel, D.S., Terrestrial ecosystems and the carbon cycle, Global Change Biol., 1, 77-91, 1995.

Schimel, D.S., M.A. Stillwell, and R.G. Woodmansee, Biogeochemistry of $\mathrm{C}, \mathrm{N}$, and $\mathrm{P}$ in a soil catena of the shortgrass steppe, Ecology, 66, 276-282, 1985

Schimel, D.S., W.J. Parton, T.G.F. Kittel, D.S. Ojima, and C.V. Cole, Grassland biogeochemistry: Links to atmospheric processes, Clim. Change, 17, 13-25, 1990.

Schimel, D.S., T.G.F. Kittel, and W.J. Parton, Terrestrial biogeochemical cycles: Global interactions with atmosphere and hydrology, Tellus Ser. $A B, 43,188-203,1991$.

Schimel, D.S., B.H. Braswell, E.A. Holland, R. McKeown, D.S. Ojima T.H. Painter, W.J. Parton, and A.R. Townsend, Climatic, edaphic, and biotic controls over carbon and turnover of carbon in soils, Global Biogeochem. Cycles, 8, 279-293, 1994.

Schimel, D., I.G. Enting, M. Heimann, T.M.L. Wigley, D. Raynaud, D. Alves, and U. Siegenthaler, $\mathrm{CO}_{2}$ and the carbon cycle, in Climate Change 1994: Radiative Forcing of Climate Change and An Evaluation of the IPCC IS92 Emission Scenarios, edited by J.T. Houghton, L.G. Meira Filho, J. Bruce, H. Lee, B.A. Callander, E. Haites, N. Harris, and K. Maskell, pp. 35-71, Cambridge Univ. Press, New York, 1995.

Schimel, D.S., VEMAP Participants, and B.H. Braswell, Spatial 
variability in ecosystem processes at the continental scale: Models, data, and the role of disturbance, Ecology, in press, 1996.

Schulze, E.D., W. De Vries, M. Hauhs, K. Rosén, L. Rasmussen, O.-C. Tann, and J. Nilsson, Critical loads for nitrogen deposition in forest ecosystems, Water Air Soil Pollut., 48, 451-456, 1989.

Spencer, R.W., J.R. Christy, and N.C. Grody, Global atmospheric temperature monitoring with satellite microwave measurements: Methods and results 1979-84, J. Climate, 3, 1111-1128, 1990.

Thompson, M.V., J.T. Randerson, C.B. Field, and C.M. Malmstrom, Constraining terrestrial net primary production from estimates of historical plant carbon uptake, paper presented at First Scientific Conference, Int. Geosphere-Biosphere Programme, Global Anal., Interpret., and Model., Garmisch-Partenkirchen, Germany, Sept. 2529, 1995.

Townsend, A.R., B.H. Braswell, E.A. Holland, and J.E. Penner, Spatial and temporal patterns in terrestrial carbon storage due to deposition of anthropogenic nitrogen, Ecol. Appl., in press, 1996.

Trumbore, S.E., Comparison of carbon dynamics in tropical and temperate soils using radiocarbon measurements, Global Biogeochem. Cycles, 7, 275-290, 1993.

Uchijima, Z., and H. Seino, Agroclimatic evaluation of net primary productivity of natural vegetations, I, Chikugo model evaluating net primary productivity, J. Agric. Meteorol. (Tokyo), 40, 343-352, 1985.

VEMAP Members, Vegetation/ecosystem modeling and analysis project: Comparing biogeography and biogeochemistry models in a continental-scale study of terrestrial ecosystem responses to climate change and $\mathrm{CO}_{2}$ doubling, Global Biogeochem. Cycles, 9, 407-438, 1995.
Vitousek, P.M., and R.W. Howarth, Nitrogen limitation on land and in the sea: How can it occur?, Biogeochemistry, 13, 87-115, 1991.

Wofsy, S.C., M.L. Goulden, J.W. Munger, S.-M. Fan, P.S. Bakwin, B.C. Daube, S.L. Bassow, and F.A. Bazzaz, Net exchange of $\mathrm{CO}_{2}$ in a mid-latitude forest, Science, 260, 1314-1317, 1993.

Zak, D.R., D. Tilman, R.R. Parmenter, C.W. Rice, F.M. Fisher, J. Vose, D. Milchunas, and C.W. Martin, Plant production and soil microoragnisms in late-successional ecosystems: A continental-scale study, Ecology, 75, 2333-2347, 1994.

Zobler, L, A world soil file for global climate modeling, NASA Tech. Memo. 87802, 1986.

B.H. Braswell, Institute for Earth, Oceans and Space, University of New Hampshire, Durham, NH 03824. (email: rob.braswell @unh.edu)

R. McKeown and D.S. Schimel, National Center for Atmospheric Research, P.O. Box 3000, Boulder, CO 80307-3000. (email: beckym@nrel.colostate.edu; schimel@ ncar.ucar.edu)

D.S. Ojima, W.J. Parton, and W. Pulliam, Natural Resources Ecology Laboratory, Colorado State University, Fort Collins, CO 80521. (email:dennis@poa.nrel.colostate.edu; bparton@ @ nrel.colostate.edu; pulliam@nrel.colostate.edu)

(Received January 16, 1996; revised May 14, 1996; accepted May 15, 1996.) 